\title{
Alfred E. Mann
}

A self-made billionaire and serial entrepreneur of numerous medical device and biotech ventures, Mann has been exemplary in his philanthropy. This has not meant that his Alfred E. Mann Foundation for Biomedical Engineering (AMFBE) has been without its critics.

Alfred E. Mann, who has spent much of his time and money combining machines with humans, is sounding like he's a bionic man himself these days. Although he's 81 , he jokes that he has dyslexia-which puts his age at 18 - and says he plans on living another 40 or 50 years.

If he did, it's likely he'd see patients using retina implants to restore their vision, bionic electro-stimulators to reclaim limb function and biotherapeutic vaccines to prevent cancer. All of those developments are being tested at companies founded by Mann.

But in dispersing Mann's considerable wealth into nonprofit institutions associated with universities, the AMFBE in Santa Clarita, California, has come under fire for allegedly tying thick strings to its endowments. For a man who believes "creating something that makes a real difference in people's lives eclipses anything you can do," and who points out that "there's more to life than materiality," the criticism must have left a bitter taste.

Mann, worth \$2.2 billion in 2006 according to Forbes' list of richest Americans, is originally from Portland, Oregon. He moved with his family to Los Angeles in 1946 to attend the University of California at Los Angeles (UCLA) after serving as a B-29 navigator in World War II. He earned BA and MS degrees in physics at UCLA, then took a job in the aerospace industry that involved pioneering work in electro-optical physics.

Five years later, the army approached him to consult on an anti-tank missile program guidance system. The army offered a contract that led to the founding of Mann's first company, Spectrolab in Sylmar, California. He eventually sold that firm to Boeing Corporation in Chicago, and overall, he has taken public or sold a dozen companies, most of them biomedical.

From those companies have come the cochlear implant (Advanced Bionics of Sylmar, now a unit of Boston Scientific, of Natick, Massachusetts), the implantable programmable insulin pump (MiniMed, now a unit of Medtronic in Minneapolis) and the rechargeable pacemaker (Pacesetter, of Sylmar, now a unit of Siemens in Munich).

From the 1990s on, he's been focusing on establishing "industrialstyle product-development organizations" on university campuses, he says. More specifically, he's been seeking to build nonprofit institutes as parts of universities, started with a $\$ 100$ million endowment from the AMFBE, which became operational two years ago.

The mission of the AMFBE is to establish two institutes per year, on 12 to 16 campuses by 2012 . The sites already selected are the University of Southern California at Los Angeles (the original prototype in 1998); Technion University in Haifa, Israel (2006); and Purdue University in West Lafayette, Indiana (2007).

But after an aborted attempt last year to fund a joint research institute at the University of North Carolina at Chapel Hill and North Carolina State University, questions surfaced in the media around just what the AMFBE wanted in return for its endowment.

Forbes reported that the University of California at Los Angeles and Johns Hopkins had turned down offers to build institutes, and pointed to intellectual property (IP) rights as the culprit. Science said that IP was the sticking point for the North Carolina schools, too, claiming that an Alfred Mann Institute (AMI) there would have had first option to license any biomedical technology or drug coming out of the universities that wasn't already contracted to another entity.

Stephen Dahms, president and CEO of AMFBE, says the media's claims "regarding the institutes are unfounded, because the media was not involved in the negotiations and are not privy to the affiliations agreements used to form the AMIs." He notes the selection of IP is a "50/50 partnership" between the university and the AMI, and "selection of IP is conducted through an executive director and a board of directors that is $50 \%$ university based."

Mann's daughter, Carla Mann Woods, is a member of AMFBE's siteselection committee as its vice president for strategic initiatives. She says the press "may have confused one of our campus visits with an offer to establish an Alfred Mann Institute."

"We've made four offers to establish institutes," she says, including the offer to the North Carolina schools (officially withdrawn by Mann). The other three became institutes, and "we've made no other offers."

Mann says his institutes address "a prominent need that everybody in the industry knows about." Although money can be found for solid research or a phase 3 product, in between "money becomes scarce and researchers must rely on venture capitalists or private companies for funding. It's becoming increasingly more difficult to do that, and that is where many of these ventures fail, and where AMI can bridge the gap."

"Creating something that
makes a real difference in
people's lives eclipses anything
you can do," says Mann.

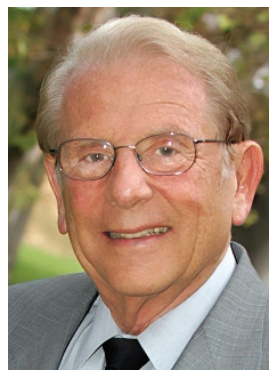

"Efforts like those of the Mann foundation are extremely important to build on what the NIH [National Institutes of Health] is trying to do," says Robert W. Baughman, associate director for technology development at the Neurology Institute at NIH. The majority of the NIH's \$28 billion annual budget is devoted to the basic science that provides the base for translational research.

Being self-made, Mann understands the value of a day's work. He has given stock in his companies to his seven children, but he "doesn't want to ruin them" by leaving them obscene sums of money. He plans to leave all but $1-2 \%$ of his fortune to helping people through technology.

Mann remains busy. He is chairman and CEO of Advanced Bionics and MannKind in Valencia, California, as well as chairman of Bioness in Santa Clarita, California; NeuroSystec in Valencia; Implanted Acoustics in Santa Clarita; and Second Sight and Quallion in Sylmar.

$\mathrm{He}$ is also involved with his Alfred Mann Foundation for Scientific Research (AMF), founded in 1985 in Santa Clarita, which is distinct from his effort with university institutes. He has adjusted his course slightly by focusing on biopharmaceuticals for diabetes and cancer at MannKind. "We have three therapeutic vaccines that marshal the body's own immune system to destroy cancer cells wherever they are in the body," he notes, adding that biotech is "how we're going to practice medicine and treat patients and how we're going to make enormous progress in eliminating some of the most devastating diseases we see today."

Ann Roberts Brice, Morristown, New Jersey 